удК 346

DOI https://doi.org/10.32837/yuv.v0i5.2256

Л. Олійник,

адвокатка, медіаторка, аспірантка

Інституту економіко-правових досліджень

імені В.К. Мамутова Національної академії наук України

\title{
ДО ПИТАННЯ СЕМАНТИЧНОГО АНАЛІЗУ ТЕРМІНУ «МОРАЛЬНА ШКОДА СУБ'ЄКТА ГОСПОДАРЮВАННЯ»
}

\author{
«Слова - такі невинні і слабкі, коли вони у словнику, \\ але якими могутніми для добра і зла вони стануть \\ у руках того, хто вміє їх поєднувати!» \\ Натаніель Готорн [1, с. 194]
}

\begin{abstract}
Актуальність дослідження. Об'єктивна реальність сьогодення випереджує людину у спробах осягнути та пояснити усі явища, що іiі оточують. Так часто трапляється й у світі юриспруденції. Нові правовідносини, інновації в праві, сучасні виклики нерідко послуговуються термінологією, яка разюче не відповідає тому наповненню, де застосовується, інколи слугує причиною нерозуміння суті проблеми чи питання або й непорозуміння на стадії перемовин, а нерідко й у судах чи певних альтернативних процедурах вирішення спорів.

Поєднання слів «моральна шкода суб'єкта господарювання» нерідко викликає не лише здивування: «яка мораль чи моральність може бути в компанії, юридичної особи чи іншого суб'єкта господарських правовідносин?», а й заперечення взагалі можливості існування моральної шкоди в суб'єкта господарювання. Останне залишимо для подальших дискусій та наукових пошуків. Актуальність же цього дослідження зумовлена власне описаною вище двозначністю розуміння / нерозуміння, неоднозначністю трактування терміну «моральна шкода суб̆єкта господарювання»
\end{abstract}

(надалі - МШСГ), відповідно, й вузькістю його застосування тощо.

Слід зауважити, що піднята у статті проблематика не була цілісним об'єктом спеціального вивчення ні в лінгвістичних, ні в юридичних колах, лише фрагментарно досліджувалися окремі питання.

Метою дослідження $€$ семантичний аналіз терміну «моральна шкода суб'єкта господарювання» крізь призму юридичного термінознавства. Об'єкт дослідження - термінологічна одиниця «моральна шкода суб'єкта господарювання» та його окремі частини: «суб'єкт», «суб'єкт господарювання», «моральна шкода».

Виклад основного матеріалу. Продовжуючи думку про те, що поєднання слів «моральна шкода суб'єкта господарювання» викликає не лише здивування, а й заперечення взагалі можливості існування моральної шкоди в суб'єкта господарювання, варто згадати слова Т. Губаєвої, яка у своїх працях закликає обережно ставитися до використання слова в юридичній мові. Цінні слова вченої є доречними не лише для законодавця чи правозастосовника, а й для вченого, що робить спроби осягнути проблематику застосування термінів. 
«Не можна забувати, - пише вона, що через слово і законодавець, і правозастосовник отримує доступ до специфічних механізмів управління мисленням і переконання людей, до влади над суспільною свідомістю. Від того, якими способами законодавець конструює правові поняття, залежить інтенсивність інформаційного впливу права та ефективність правового регулювання загалом [2, с. 27]. Продовжує думку Т. Губаєвої дослідниця юридичної термінології М. Любченко, стверджуючи, що слово в юридичній мові набуває статусу правового знаку, який не є абстрактно-символічним поняттям, навпаки, це чітко означений матеріальний носій інформації, акумульованої та сформульованої у словесному образі, що є зрозумілим для носія певної правової культури, в межах якої побутує цей знак [3, с. 26].

Розпочинаючи аналіз терміну МШСГ, зауважимо, що доцільним $€$ означення понять «термін», «термінологія» та «юридичний термін».

У загальноприйнятому розумінні термін - це спеціальне слово або словосполучення, що вживається в мові фахівців і має точно окреслене значення [4, с. 230]. Ознаками або швидше вимогами, що характеризують термін, є такі: однозначність, точність, стилістична нейтральність. Термін характеризується системністю, наявністю чіткої дефініції, відсутністю експресіі, пластичністю або гнучкістю, здатністю до творення похідних термінів, мовною досконалістю, стислістю, милозвучністю, легкістю для запам'ятовування, відповідністю міжнародним стандартам [4, с. 230].

Важко знайти вченого чи правозастосовця, які б не використовували терміни у своїй діяльності. У цьому контексті важливо сказати про інтуїтивне сприйняття кожним семантичного змісту «терміну», однак сьогодні не існує однозначного трактування безпосередньо поняття «термін». На рівні інтуїції «термін» пов'язується 3 конкретною фаховою галуззю та протиставляється відповідним загальновживаним мовним одиницям. Уже згадувана $M$. Любченко, обгрунтовуючи слова А. Піголкина про те, що кожний термін - це слово (або їх сукупність), але не кожне слово - термін, наголошує на необхідності з'ясування, що таке термін, які функції він виконує і як співвідносяться між собою термін і слово. Так, «термін» походить від латинського «terminus», що перекладається як «межа», «кордон». Така етимологія пов'язана перш за все 3 тим, що термін має чітко окреслене значення, тверді межі змісту, а також слугує для відмежування одних понять від інших. Натепер існує біля 3000 визначень цього поняття [3, с. 27-28].

У Великому тлумачному словнику української мови «термін» визначається як слово або словосполучення, що означає чітко окреслене спеціальне поняття якої-небудь галузі науки, техніки, мистецтва, суспільного життя тощо [5, с. 1444].

Що ж до терміну МШСГ, то за своєю суттю цей термін являє собою сукупність слів, пов'язаних між собою, тобто словосполучення. Так, Н. Власенко, вивчаючи мову права, визначає словосполучення як відносно стійкий змістовний зв'язок між словами [6, с. 102], а за А. Полешко словосполучення можуть бути термінізованими, тобто це смислові одиниці, які несуть відповідну інформацію, мають тільки таке, а не вільне оформлення, тільки таке, а не вільне значення [7, с. 32]. Термінологічні сполучення можуть бути дво-, трита багатокомпонентними. Компонентами термінологічних словосполучень $€$ терміни-слова, які за лексико-граматичною належністю поділяються на іменники (суд, право, шкода, суб'єкт, господарювання), прикметники (моральний, нематеріальний, правовий), дієслова (діяти, легалізувати, відшкодовувати), прислівники (умисно, умовно). Термінологічні 
сполучення складаються зі стрижневого й залежних компонентів, які уточнюють, конкретизують значення основного терміна (право на життя, адміністративне право, злочин проти життя). Н. Артикуца дуже влучно наголошує, що словосполучення репрезентують найпродуктивніший спосіб сучасного термінотворення, оскільки сприяють точності й однозначності не лише термінологічних одиниць, а й тексту закону [8, с. 41].

Думка про те, що термінологічні словосполучення більш зручні, ніж однослівні терміни, оскільки розкривають і уточнюють загальні юридичні терміни, не нова, і зустрічається в роботах і Т. Губаєвої, і А. Полешка. B. Савицький же зауважує, що основна причина виникнення термінів, утворених із двох і більше слів необхідність виокремити деяку множину предметів із класу за будь-якою ознакою, що називається видовою відмінністю [9, с. 26]. За своєю мовною природою багатослівні складені терміни є сталими, закритими словосполученнями (тобто такими, що відтворюються в мові в певній усталеній формі, не допускаючи включення нових слів або заміни відповідних слів довільно взятими) і хоч вільними (тобто такими, де значення словосполучення загалом випливає зі значення слів компонентів), але 3 певними обмеженнями (не можна, зокрема, на свій розсуд змінювати порядок слів) [10, с. 72]. У випадку, наприклад, поєднання чотирьох слів, прикметника та трьох іменників, «моральна» та «шкода» «суб'єкт» «господарювання» із використанням правил погодження слів у єдиний термін МШСГ ми отримали юридично термінізоване словосполучення, яке можна вважати окремою мовною одиницею.

Загалом, під час поєднання термінів у термінологічні словосполучення, за вченням А. Полешка, семантичні зміни відбуваються у двох напрямках:

- переосмислення немає, термін не виходить із поля певного поняття, але зазнає різноманітних змін. Наразі спостерігається така закономірність: чим більш абстрактним, загальним $€$ термін, тим кардинальніших змін він зазнає, тим вільніше сприймає будь-які доповнення, тим ширшою $€$ його валентність, тобто можливість поєднуватися 3 іншими поняттями $[7$, с. 34];

- має місце те чи інше переосмислення загального терміну, утворення різних понять. За наявності багатозначності терміну саме словосполучення надає можливість «відсікти» значення, які не відповідають поняттю, про яке цього разу йдеться. У словосполученні й досягається необхідна точність та однозначність [7, с. 34].

У контексті нашого дослідження спробуємо визначити, чи відбувається те чи інше переосмислення слова «суб'єкт», чи значення його залишається незмінним при утворенні термінологічних словосполучень. Так за Українським тлумачним словником слово «суб'єкт» має більше восьми різнопланових значень. Тобто за утворення словосполучень із цим словом щоразу відбуватиметься переосмислення терміну. Однак, якщо обрати одне із значень слова «суб'єкт», наприклад: особа чи організація як носій певних прав та обов'язків, в якості відправної точки - то саме слово у поєднанні 3 іншими може набувати різних відтінків та значень: «суб'єкт господарювання», «суб’єкт оподаткування», «суб’єкт кримінального правопорушення» тощо, але значення його залишиться незмінним.

Вказане вище дає змогу дійти висновку, що за поєднання терміну «суб'єкт» у термінологічні словосполучення його семантичне значення змінюється у двох напрямках: спочатку у напрямку переосмислення, а потім - набуває специфічних відтінків, залишаючи первісне значення незмінним.

Для подальших розвідок досліджуваного терміну слід детальніше зупи-

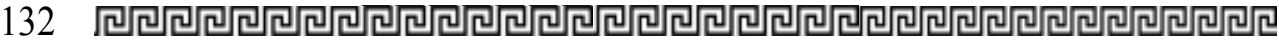


нитися на мові права та особливостях юридичної термінології.

Яскравими висловлюваннями дослідник В. Русанівський характеризує мову права: «у сфері правовідносин існує особлива мова як знакова система, що служить засобом прояву думок, професійного спілкування юристів, засобом передачі професійної (правової) інформації. Ця знакова система включає спеціальні юридичні терміни, що мають особливий правовий зміст, і називається мовою права або юридичною мовою. У межах цієї семантичної системи визначають дві семантичні категорії: висловлювання, імена (загальні, одиничні, абстрактні, конкретні) та юридичні терміни («право», «закон», «правопорушення», «злочин», «покарання» і так далі), які мають специфічний зміст і предметно-галузеве значення» [11, с. 13].

Важко сперечатися 3 тим, що формулювання права повинні бути визначеними й однозначними. Це твердження, яке сприймалося за абсолютну істину і за часів Римської імпеpii,, і в сьогоденні, ставить сучасних мовознавців та юристів перед викликом постійного пошуку відповідної термінології, яка б відповідала тому наповненню, де й як застосовується, особливо за умов стрімкого розвитку нашого суспільства та виникнення все нових і нових правовідносин. Наприклад, коли вчений відкриває нове явище, він намагається віднайти цьому явищу нове ім'я і в процесі такого пошуку змушений звертатися до загальновживаної мови, де він знаходить таке слово, яке за значенням близьке до нового поняття. У такій ситуації старе слово отримує нове смислове навантаження. I в цьому значенні воно стає деякою метафорою, яка здатна індивідуалізувати новий об’єКт [12, с. 10].

Для визначення поняття «юридичний термін» автор вважає за доцільне навести дві дефініції, не як найбільш правильні чи суперечливі, а як такі, що є універсальними. Так, за М. Люб- ченко, юридичний термін - це слово або словосполучення, яке виступає узагальненим найменуванням певного правового поняття або поняття, яке не є правовим, але в результаті функціонування у сфері юриспруденції набуває специфічних значеннєвих відтінків, вводиться в обіг представниками юридичної науки або законодавцем, характеризується емоційною нейтральністю та відносною стійкістю [3, с. 45]. Згадувана вище Н. Артикуца пропонує інше визначення юридичного терміну: слово або словосполучення, що виражає поняття з правової сфери суспільного життя і має визначення (дефініцію) в юридичній літературі (законодавчих актах, юридичних словниках, науково-правових працях) [13, с. 1].

Надалі слід торкнутися проблематики вмотивованості юридичного терміну МШСГ у контексті розуміння таких юридичних термінів як «моральна шкода» та «суб'єкт господарювання» .

Вчені, серед них і такі, як М. Любченко, В. Примак, неодноразово стверджували, що більшості юридичних термінів притаманна метафоричність як результат переносного вживання слова. Із цим твердженням важко не погодитися, зокрема й у контексті досліджуваного терміну. Саме метафоричне означення шкоди як моральної перш за все протиставляє ї матеріальній, хоч і подальша конкретизація в тому, що йдеться про моральну шкоду, завдану лише суб'єктам господарювання, викликає певні труднощі розуміння та застосування, що дає змогу зробити такий висновок: саме метафоричність вживання цього словосполучення як терміну створює передумови його використання у світі юриспруденціі.

Продовжуючи розвідку проблематики вмотивованості терміну, постає питання про шляхи іiі досягнення з метою зрозумілості, чіткості розуміння та застосування термінів, а також усвідомлення зв'язку між 
значенням та звуковою й структурною побудовою терміну. Як згадувалося вище, М. Любченко стверджує, що вмотивованість терміну досягається шляхом його метафоризації. [3, с. 196]. Зазначений ряд можливих шляхів досягнення вмотивованості терміну МШСГ варто продовжити такими інструментами, як асоціації та аналогії, що стане наступним етапом дослідження в контексті з історичним походженням терміну.

Проблему вмотивованості терміну також грунтовно досліджував Д. Лотте, який залежно від рівня вмотивованості термінів поділяє їх на «правильно зорієнтовані, нейтральні і неправильно зорієнтовані». Чим більшою мірою буквальне значення терміну відповідає змісту поняття, з яким він співвідноситься, тим правильніше зорієнтованим він є [14, с. 67].

Розглядаючи вмотивованість терміну МШСГ та констатуючи, що сам термін $є$ багатокомпонентним, звернемось до його окремих частин «суб'єкт», «суб'єкт господарювання», «моральна шкода».

Як зазначалося вище, за Українським тлумачним словником, слово «суб'єкт» має більше восьми різних різнопланових значень. Для потреб цього дослідження обмежимося такими:

- особа, група осіб, організація, яким належить активна роль у певному процесі;

- особа чи організація як носій певних прав та обов'язків [15, с. 1423].

Надаючи слову «суб'єкт» забарвлення та означення сфери застосування, отримуємо термін «суб'єкт господарювання». В. Мамутов зазначав, що суб'єкти господарювання бувають різними [16, с. 273]. Водночас вчений терміни «суб'єкт господарювання», «суб'єкт господарської діяльності», «господарюючий суб'єкт», «господарююча організація» вважав синонімами. Аналіз та пошук дефініцій терміну «суб'єкт господарювання» не є метою дослідження, тому для потреб останнього автор користується законодавчим визначенням терміну. Так, за змістом статті 55 Господарського кодексу України суб'єктами господарювання визнаються учасники господарських відносин, які здійснюють господарську діяльність, реалізуючи господарську компетенцію (сукупність господарських прав та обов'язків), мають відокремлене майно і несуть відповідальність за своїми зобов'язаннями в межах цього майна, крім випадків, передбачених законодавством. Суб’єктами господарювання є:

- господарські організаціі - юридичні особи, створені відповідно до Цивільного кодексу України, державні, комунальні та інші підприємства, створені відповідно до цього Кодексу, а також інші юридичні особи, які здійснюють господарську діяльність та зареєстровані в установленому законом порядку;

- громадяни України, іноземці та особи без громадянства, які здійснюють господарську діяльність та зареєстровані відповідно до закону як підприємці [17].

Тобто, термін «суб'єкт господарювання» $€$ широким поняттям, яке включає всіх учасників господарських взаємовідносин. Однак авторський колектив науково-практичного коментаря Господарського кодексу України за загальною редакцією В. Галунька наголошує на тому, що «окремі громадяни, якщо вони здійснюють підприємництво без створення підприємства, також мають визнаватися суб'єктами господарювання, а не суб'єктами цивільного права, як вважалося раніше, хоч їхній правовий статус потребує детального дослідження» [18, с. 118].

Продовжуючи розвідки багатокомпонентного терміну МШСГ, розглянемо термін «моральна шкода». Так, Український тлумачний словник визначає словосполучення «моральна шкода» як страждання, заподіяні фізичній особі внаслідок фізичного 
або психічного впливу, що спричинило погіршення або позбавлення можливостей реалізації ним своїх звичок і бажань, погіршення відносин з іншими людьми [15, с. 1660]. Поряд із тим, певна ефемерність самих термінів «мораль», «моральність», відповідно й «моральна шкода» дає змогу погодитися з висновками В. Примака про те, що природа моральної шкоди $€$ надто відмінною від інших можливих різновидів, умовно кажучи, фактичної, а не формально-юридичної немайнової шкоди. I якщо зазначену «фактичну» шкоду можна достовірно виявити та зафіксувати, то будь-яке судження за завдану моральну шкоду за всіх обставин залишатиметься імовірнісним умовиводом, позбавленим абсолютної достовірності [19, с. 250].

Очевидно й те, що словосполучення «моральна шкода» у побутовому вживанні зрідка застосовується для характеристик певних немайнових втрат чи змін підприємств, компаній, юридичних осіб та інших юридичних фікцій.

Тому, використовуючи класифікацію Д. Лотте, термін МШСГ умовно можна вважати неправильно зорієнтованим, адже дослівне його тлумачення, а не в метафоричному чи асоціативному аспекті, свідчить про внутрішню суперечність досліджуваного терміну.

Аналізуючи наведені вище визначення, тлумачення та думки вчених, можна зробити висновок про те, що саме слово «моральна» у терміні МШСГ вносить певний дисонанс чи викликає хибні асоціації. Досліджуючи роботи вчених, наприклад, В. Примака, М. Мельника, які у своїх працях використовують термін МШСГ або інші варіації поєднань терміну «моральна шкода» та «юридична особа», «компанія», «суб’єКт підприємництва» або ж торкалися у своїх розвідках питання компенсації такого типу шкоди для різноманітних суб'єктів за виключенням фізичних осіб, можна дійти висновку про сино- німічне використання слів «моральна» і «нематеріальна».

Згадаємо також, що статтею 16 Цивільного кодексу України визначено, що одним із способів захисту цивільних прав та інтересів може бути відшкодування моральної (немайнової) шкоди. У статті 23 Цивільного кодексу Украіни законодавець дещо звужує змістовне навантаження поняття моральної шкоди для юридичної особи, констатуючи, що моральна шкода полягає у приниженні честі та гідності фізичної особи, а також ділової репутації фізичної або юридичної особи [20].

До визначення змісту досліджуваного поняття звертався й Пленум Верховного Суду України у Постанові № 4 від 31 березня 1995 р. «Про судову практику в справах про відшкодування моральної (немайнової) шкоди». Зокрема, пунктом 3 згаданого документу визначається, що моральну шкоду слід трактувати як втрати немайнового характеру внаслідок моральних чи фізичних страждань чи інших негативних явищ, заподіяних фізичній чи юридичній особі незаконними діями або бездіяльністю інших осіб. [21]. Надалі Пленум конкретизує зміст поняття саме для юридичних осіб, але використовує вже термін «немайнова шкода, заподіяна юридичній особі». Зокрема, немайновою шкодою, заподіяною юридичній особі, слід називати втрати немайнового характеру, що настали у зв'язку з приниженням іï ділової репутації, посяганням на фірмове найменування, товарний знак, виробничу марку, розголошенням комерційної таємниці, а також вчиненням дій, спрямованих на зниження престижу чи підрив довіри до iii діяльності [21].

Аналізуючи згадувані вище документи, можна зробити висновок, що законодавець та Пленум Верховного Суду України терміни «моральна шкода» та «немайнова шкода», 
заподіяна юридичній особі, як і деякі вчені, вважає синонімами.

висновки. Здійснене дослідження дає можливість зробити висновки про те, що термін «моральна шкода суб’єкта господарювання» за класифікацією Д. Лотте умовно можна вважати неправильно зорієнтованим та таким, що містить внутрішню суперечність, водночас саме слово «моральна» у досліджуваному терміні вносить певний дисонанс й може викликати хибні асоціації. Проте досліджені випадки вживання терміну МШСГ, інші варіацій поєднань терміну «моральна шкода» та «юридична особа», «компанія», «суб’єкт підприємництва» в наукових працях чи нормах права свідчать про синонімічне використання слів «моральна» і «нематеріальна».

Відтак, автор вважає за можливе поставити питання про те, чи не відображатиме більш точне смислове навантаження вживання слова "нематеріальна» замість «моральна» в контекстах, коли йдеться про втрати немайнового характеру, яких зазнають суб'єкти господарювання і чи не сприятиме більш точному розумінню вживання терміну саме «нематеріальна шкода суб'єктів господарювання». Саме тому в межах отриманих результатів можна намітити перспективу подальшого дослідження питання походження й сенсового та змістовного наповнення терміну «нематеріальна шкода суб'єкта господарювання» .

У статті аналізується сучасна проблематика вживання багатокомпонентного терміну «моральна шкода суб'єкта господарювання» $у$ сферах правозастосовної та наукової діяльності крізь призму семантичного аналізу та юридичної термінологіі. Автор, поділяючи думку про те, щзо належна лінгвістична якість юридичних текстів сприяє розумінню $i$ без того складних правових ідей та створює середовище для однозначного застосування нелегких юридичних термінів, робить спробу зрозуміти причину існування внутрішньӧ суперечності досліджуваного терміну.

Також у дослідженні виконано семантичний аналіз значень окремих слів, термінів, словосполучень, серед них $i$ термінологічних, щз $\epsilon$ складовими досліджуваного терміну «моральна шкода суб'єкта господарювання», а саме: «суб'єкт», суб'єкт господарювання», моральна шкода». Зроблено огляд вживання синонімічного до слова «моральний» слова «нематеріальний». Окрім того, автор торкається проблематики вмотивованості юридичного терміну «моральна шкода суб’єкта господарювання» та пошуку шляхів ї досягнення з метою зрозумілості, чіткості розуміння та застосування терміну, а також усвідомлення зв'язку між значенням та звуковою й структурною побудовою терміну. Автором проаналізовано термін "моральна шкода суб'єкта господарювання» за категоріями, виділеними Д. Лотте, залежно від рівня його вмотивованості та досліджено семантичні зміни, щзо відбуваються з окремими елементами терміну в разі поєднання їх у термінологічні словосполучення на прикладі терміну «суб’єкт». Ми обгрунтовуємо тезу про те, що саме слово «моральна» у досліджуваному терміні вносить певний дисонанс і може викликати хибні асоціаціï, та робимо припущення, щзо вживання слова «нематеріальна» замість «моральна» в контекстах, коли йдеться про втрати немайнового характеру, яких зазнають суб'єкти господарювання, зокрема й у контексті терміну «моральна шкода суб'єкта господарювання», сприятиме більш точному його розумінню та вживанню.

Ключові слова: моральна шкода суб'єкта господарювання, нематері- 
альна шкода суб'єкта господарювання, суб'єкт господарювання, семантика, термінологічні словосполучення.

Oliinyk L. On the issue of semantic analysis of the term "moral damage of the business entity"

This article analyzes the current issues of using the multicomponent term "moral damage of the business entity" at the modern stage of law enforcement and researches through the prism of semantic analysis and legal terminology. The author agrees with the opinion that the high linguistic quality of legal texts leads to the understanding of the complex legal ideas and creates an environment for unambiguous application of difficult legal terms and tries to understand the reason for the internal contradiction of the term.

Also, the study performed a semantic analysis of the meanings of separate words, terms, phrases, including terminological, which are parts of the studied term "nonpecuniary damage of the business entity", namely: "subject", "business entity", "non-pecuniary damage". The use of the word "non-pecuniary", "non-material" as a synonym with the word "moral" is also reviewed. In addition, the author describes and analyzes the issue of motivation of the legal term "moral damage of the business entity" and finding ways to achieve it in order to understand, clearly apply the term, as well as awareness of the connection between meaning, sound and structure of the terms. In addition, the author analyzes the term "moral damage of the business entity" in the categories identified by D. Lotte depending on the level of its motivation and explores the semantic changes that occur with particular elements of the term when they combined into terminological phrases on the example of the term "subject". The researcher substantiates the statement that the word "moral" in the studied term introduces a certain dissonance and may cause false associations and suggests that the use of the word "non-material" instead of "moral" in contexts when it comes to non-material losses suffered by business entities, including in the context of the term "moral damage of the business entity" will contribute to a more accurate understanding and application.

Key words: moral damage of the business entity, non-pecuniary damage of the business entity, non-material damage of the business entity, business entity, semantics, terminological phrases.

\section{Література}

1. Борг Дж. Мистеитво говорити. Таємниці ефективного спілкування / пер. з англ. Н. Лазаревич. Харків : вид-во «Ранок» Фабула, 2020. 304 c.

2. Губаева Т. Язык и право. Искусство владения словом в профессиональной юридической деятельности. Москва : Норма: Инфра-М, 2010. 160 c.

3. Любченко М. Юридична термінологія: поняття, особливості, види : монографія. Харків : Права людини, 2015. $280 \mathrm{c}$.

4. Ковтун I.I. Словотвірна та структурно-семантична характеристика юридичної термінології. Лінгвістичні дослідження. 2012. Bun. 34. С. 229-236.

5. Великий тлумачний словник української мови / уклад. і гол. ред. В.Т. Бусел. Киёв-Iрпінь: Перун, 2005. 1728 с.

6. Власенко Н.А. Язык права: монография. Иркутск : Вост.-Сибир. книж. изд-во: Норма-плюс, 1997. 176 с.

7. Полешко А. Конкретизація юридичних термінів у термінологічних словосполученнях. Рад. право. 1976. № 9. С. 32 .

8. Артикуца Н.В. Законодавчі терміни та їх визначення. Наукові записки Нац. ун-ту «Києво-Могилянська академія». Київ, 2009. Т. 90 : Юридичні науки. С. 41.

9. Савиикий В.М. Язык проиессуального закона. Вопросы терминологии / под ред. А.Я. Сухарева. Москва : Наука, 1987. $228 \mathrm{C}$

10. Полешко А. Юридичні поняття, що передаються словосполученнями. Рад. право. 1977. № 2. С. 72 . 
11. Русанівський В. Структура лексичної $i$ граматичної семантики. Киї : Наук. думка, 1988. 240 c.

12. Толкачова Н.E. Семантична структура давньоруської юридичної звичаєвої термінологіі. Бюл. М-ва юстиції України. 2008. № 2. С. 10-18.

13. Артикуца Н.В. Основи вчення про юридичний термін $i$ юридичну термінологію. URL: http: / / ekmair.ukma.edu.ua/ bitstream/ handle / 123456789 / 2457 / artykytsa_ osnovy_vchennya.pdf?sequence $=1$ (dama звернення: 09.10.2021).

14. Лотте Д.С. Основы построения научно-технической терминологии. Вопросы теории и методики. Москва: Изд-во АН СССР, 1961. 160 с.

15. Український тлумачний словник, тезаурус / за редакиією В. Бусела. Київ-Iрпінь : Перун, 2016. 1692 c.

16. Хозяйственное право : учебник / под редакцией В.К. Мамутова. Киев : Юринком Интер, 2002. 910 с.

17. Господарський кодекс Украіни : Закон України від 16 січня 2003 р.
№ 436-IV / Верховна Рада України. URL: https: / / zakon.rada.gov.ua/laws / show/436-15\#Text (дата звернення: 08.10.2021).

18. Науково-практичний коментар Господарського кодексу України / за загальною редакцією В.В. Галунька. Киї : ВД «Професіонал», 2018. 751 с.

19. Примак В. Відшкодування моральної шкоди на засадах справедливості, розумності, добросовісності. Київ : Юрінком Iнтер, 2014. $431 \mathrm{c}$.

20. Цивільний кодекс Украінни : Закон України від 16 січня 2003 р. № 435-IV / Верховна Рада Украïнu. URL: https: / / zakon.rada.gov.ua/ laws/show/435-15\#Text (Jama звернення: 08.10.2021)

21. Про судову практику в справах про відшкодування моральної (немайнової) шкоди : постанова Пленуму Верховного Суду України № 4 від 31 березня 1995 р. База даних «Законодавство України». URL: https: / / zakon.rada.gov.ua/ laws/show/ v0004700-95\#Text (дата звернення: 08.10.2021). 